\title{
In search of weighty matters
}

\section{A hard look at the 45-year quest to detect gravitational radiation.}

\section{Gravity's Shadow: The Search for Gravitational Waves \\ by Harry Collins \\ University of Chicago Press: 2004. 864 pp. \\ \$100, $£ 70$ ( $h b k$ ); \$39, £27.50 (pbk) \\ Virginia Trimble}

A distinguished colleague advised me not to review Harry Collins' book to "avoid the controversy". I think, however, that no discernible controversy remains. The physics and astronomy community has recognized for 30 years that gravitational radiation exists but that Joe Weber didn't discover it (roughly the first half of the book). And in the past decade, a particular sort of detector, called a free-mass interferometer, has pretty much wiped the competition off the face of the Earth (the second half of the book). The best-known and most expensive (well, it's American) version of the winner is called LIGO, the Laser Interferometer Gravitational Wave Observatory. Collins describes carefully how it won out over bar and sphere detectors and how it has (so far) been designed, managed, built and debugged. The single most salutory lesson he draws is that "the more money you want to spend on science, the less expert will the decision makers be".

What is gravitational radiation? Well, to produce light (electromagnetic radiation) you wiggle electric charges around; to produce gravitational radiation you wiggle masses around. There are technical differences in the polarization, for example, but the main difference is that gravitational radiation is the weaker by a factor of $10^{40}$. This means the masses that wiggle have to be of astronomical size to stand any chance of detection, so billion-dollar projects are currently under way to try and achieve this.

Collins is director of the Centre for the Study of Knowledge, Expertise and Science at Cardiff University, UK. The search for gravitational radiation (waves in current parlance; he explains why) has been his most abiding interest, with the interviews reported in the present volume dating from 1972 to 2003. The book is not very easy going for a physical scientist. I caught at least 50 technical terms and concepts whose meanings I could not have guessed or would have guessed wrong, because (like energy and momentum in physics) they are everyday words used in non-everyday senses, such as moral integration and colonial cringe.

Is it worthwhile for a natural scientist to master some of these? Probably. Ornithology, pace Richard Feynman, is useful to birds through the designation and protection of

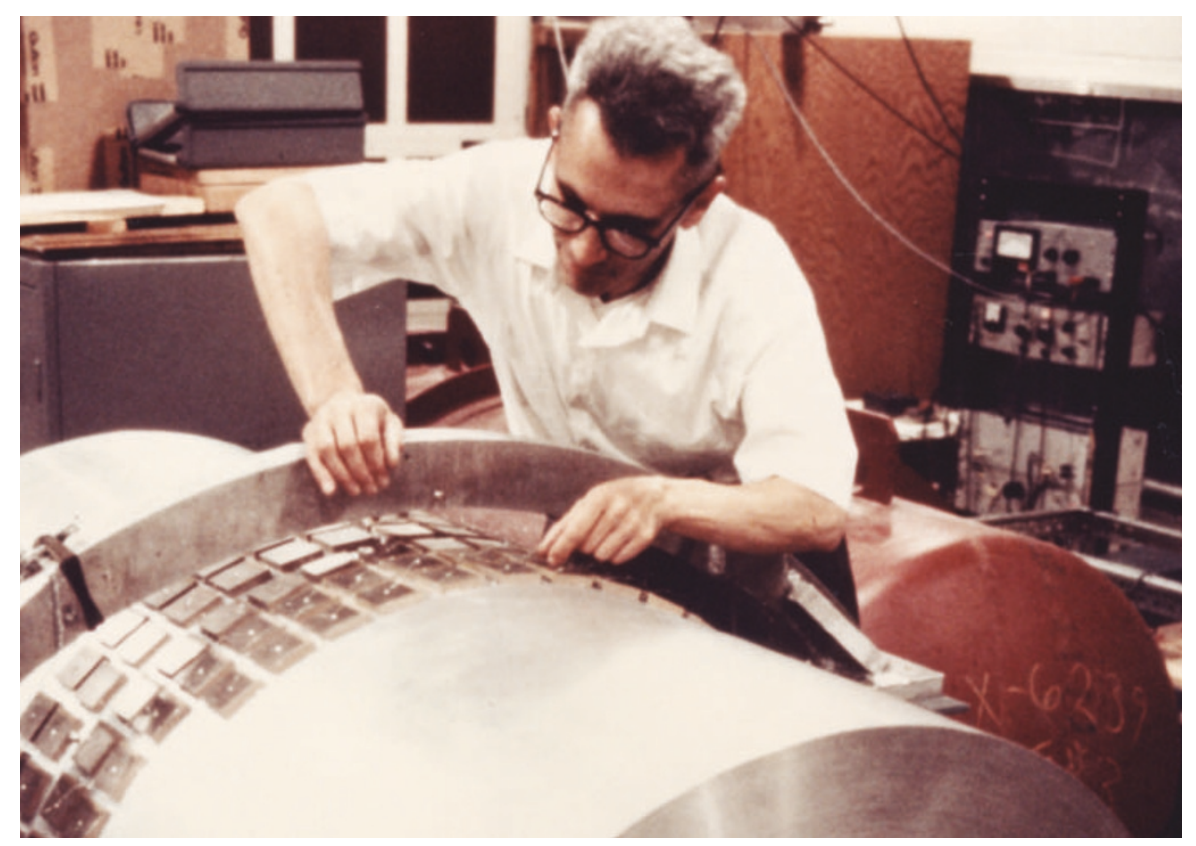

Looking for clues: Joe Weber used bar detectors in the 1960 s to search for gravitational radiation.

endangered species, although the birds don't knowit.

Collins coins the term 'Pascalian funding', for instance, to describe why government agencies in 1984 began supporting Weber's work on coherent neutrino scattering (with principles later applied to bar detectors for gravitational waves). The idea is that some things would be so important if they worked that investment makes sense even if there is only a very small probability of success. Pascal had in mind belief in a deity. The coherent neutrino process would have made submarines clearly visible under the oceans via emission from their nuclear reactors, though the explanation given of the physics is unclear because the author fails to mention the closest working analogy, Mossbauer scattering of gamma rays. The Star Wars missile defence system and cold fusion, whose funding has puzzled many physicists, probably also come under the Pascalian rubric.

Collins' discussion of evidential collectivism and individualism should ring bells with astronomers who have noticed the very different data release patterns of the Sloan Digital Sky Survey (let it all hang out) and the Wilkinson Microwave Anisotropy Project (release nothing until the team agrees, and then only a final product) and supposed that one must surely be wrong. Both can be right. The Sloan team are evidential collectivists who wish to involve the wider community in the process of assessment from an early stage, while the Wilkinson team are evidential individualists who believe they should take full responsibility for the validity and meaning of a result before it leaves their laboratory.

New in this book is a metaphor of a dam of generally accepted ideas and experimental results holding back a lake of active work, within which a small island holds a few unconventional workers, Weber of course among them. Add the now common phrase "voted off the island", and you will have a fair picture of what happened. Between about 1972 and 1976, most of the physics community decided that the early reports of evidence for gravitational radiation could not have been right, and thereafter reacted to publications and conference talks by Weber and his colleagues as if they simply did not exist.

The author misses some points. A footnote mentions that the two messiest offices he ever saw were those of Weber and of Ron Drever, architect and major builder of the 40-metre prototype for LIGO, who was summarily removed from the team in 1992. Collins seems not to have realized that each had been suddenly evicted from a large laboratory and was required on almost no notice to squeeze many years of notes, records and spare parts into an average-size faculty office.

Contributory expertise is what is needed to do science. Interactional expertise is sufficient for communicating about it: "You listen a good low-temperature physics," as Lev Landau once said to the wife of a colleague. Collins describes himself as having interactional expertise in gravitational-wave detection, but might have benefited from additional advice by contributory experts. 
My teeth were set on edge by reference to "the stable form of uranium", a violation of Kepler's second law in a description of how the Earth's orbit would change under various circumstances, and by "the rest mass of the neutrino is $4 \mathrm{eV}$ ".

Collins has been well served by his editor and publisher, but not perfectly. There are un-sort-out-able mismatches between text and index, references and figures; acronyms in the second half of the alphabet go undecoded; several well-known names are misspelled. And readers are informed that Weber's death occurred "on September 31, 2000". Well, Joe always said he could do things that other people couldn't, but there are limits.

Incidentally, my adviser was partly right: I should not have agreed to review this book. It is very much harder to hear harsh, sometimes false, things said about one's spouse after he can no longer defend himself. I am not alone in this feeling. Carvel Gold, widow of Thomas Gold, whose work was also far from universally accepted (see Nature 430, $415 ; 2004$ ), says the same thing.

Virginia Trimble is at the University of California, Irvine, California 92697-4575, USA. She and Joe Weber were married from 16 March 1972 until his death on 30 September 2000.

\section{Watson's way with words}

\section{The Writing Life of \\ James D. Watson \\ by Errol C. Friedberg \\ Cold Spring Harbor Laboratory Press: 2005. 193 pp. \$25, £18}

\section{Lewis Wolpert}

The Double Helix would on its own have established James Watson's reputation as a writer: it is the only book about science to appear in both the board's and the readers' lists of the Modern Library's top 100 nonfiction works. But Watson's textbooks have also given scientists, particularly students, a deeper understanding of genes and cells. And his popular-science books have given the public a new image of scientific research. The Writing Life of James D. Watson examines these achievements.

Watson was brought up to believe in the importance of books and reliable knowledge. He read widely and particularly enjoyed books by Graham Greene and Arrowsmith by Sinclair Lewis. Reading Erwin Schrödinger's What is Life? at the age of 17, Watson became convinced that genes were the essence of life and decided devote his own to their study. By the age of 25 he had, with Francis Crick, discovered the double-helix structure of DNA.

In relating this story in The Double Helix,

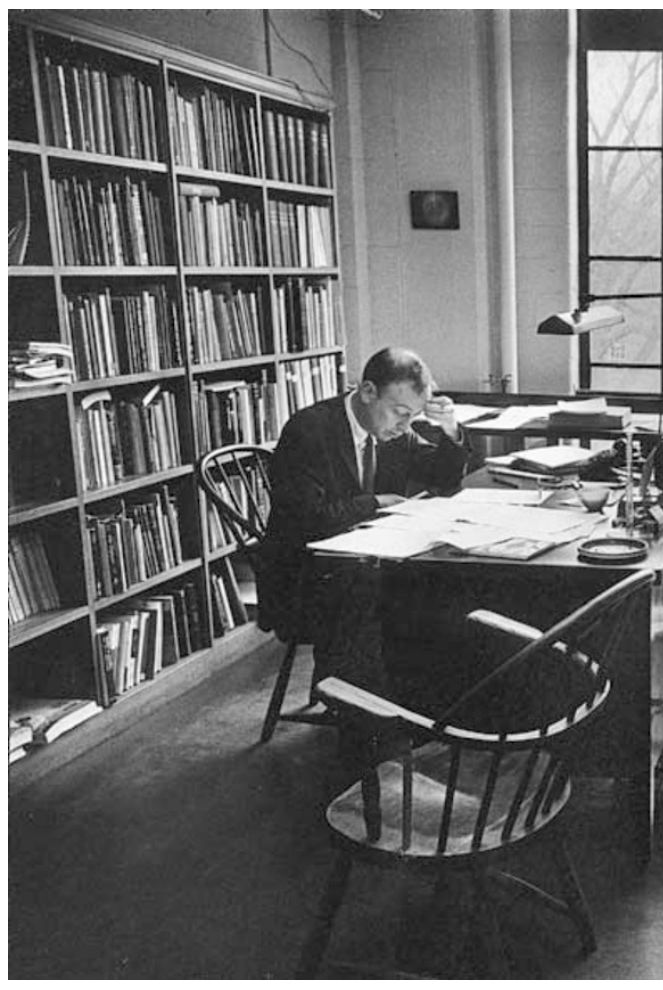

The write idea? In The Double Helix, James Watson gave a personal account of the quest for the structure of DNA.

Watson set out to produce a good story that the public would enjoy as much as The Great Gatsby. He started writing in 1962 with the working title "Honest Jim", which is illuminating in itself. The Writing Life of James D. Watson includes images of both the handwritten manuscript and the galley proofs. Indeed, almost half of Friedberg's book is devoted to photographs of text and letters, and of Watson and friends - they take up too much space, I think.

A draft of The Double Helix sent to Crick and Maurice Wilkins, a co-discoverer of the double helix, began: "I have never seen Francis Crick in a modest mood.” This upset them so much that they threatened legal action. Harvard University Press was due to publish the book, but concerns about its libellous potential, and Watson's refusal to change the text, caused them to withdraw, so Athenaeum Press published it instead. Watson was delighted that Lawrence Bragg agreed to write a foreword.

The great X-ray crystallographer J. D. Bernal could not put the book down, but thought it was particularly unfair to Rosalind Franklin. Initial reviews were mixed, but Peter Medawar wrote that "it will be an enormous success, and deserves to be so - a classic in the sense that it will go on being read." He was, as usual, right. Yet Crick found it difficult to take Watson's account seriously, although he did appreciate the quality of the writing.

Watson's skill as a writer is illustrated by this description of Rosalind Franklin. "Though her features were strong, she was not unattractive and might

even have been quite stunning had she taken even a mild interest in clothes. This she did not. There was never lipstick to contrast with her straight black hair, while at the age of thirty-one her dresses showed all the imagination of English bluestocking adolescents." Would that other scientists could write as well as that. Of his later memoir Genes, Girls and Gamow, some said that his style broke new ground with its postmodern innovatory syntax, but others were critical of both its literary style and its content. It is a pity that there are few examples of Watson's writing in Friedberg's book, nor any real analysis of the way he writes.

In all Watson's writing - from director's reports for the laboratory at Cold Spring Harbor to the popular-science books $A$ Passion for DNA and The DNA Story his strong character emerges: his sarcasm, criticism and praise make it clear what he thinks. His love of science and DNA always comes through, as does his contempt for his enemies. 